\title{
Conhecer para Humanizar: Caracterização do Perfil de Mulheres que Denunciaram a Violência em um Município do Interior Paulista
}

\author{
Pierine, Andrea Silveira Machado; Machado, Dinair Ferreira; Conti, Elaine Teixeira \\ da Costa; Almeida, Margareth Ap. Santini de; Castanheira, Elen Rose Lodeiro \\ Prefeitura Municipal de Botucatu - Smas - Creas — deiamdo@gmail.com
}

Introdução: a violência contra a mulher é um sério problema social e histórico que ganhou visibilidade na contemporaneidade, especialmente no campo de saúde pública. Além disso, constitui uma das principais formas de violação dos direitos humanos. a prática de violência passa a ser considerada crime com a promulgação da Lei Maria da Penha 11.340/06, sendo de responsabilidade dos profissionais a notificação compulsória no território nacional, conforme a Lei no 10.778/03. Contudo, essa problemática se torna invisível nos serviços de saúde justamente pela dificuldade dos profissionais em reconhecê-la como de sua responsabilidade. Nesse sentido, é importante a realização de estudos que explicitem e aproximem os perfis de mulheres vitimizadas aos profissionais de saúde, para que, além da notificação estes consigam trabalhar a prevenção e reabilitação por meio de um atendimento humanizado. Objetivos: Caracterizar o perfil de mulheres vítimas de violência doméstica que denunciaram os parceiros na Delegacia de Defesa da Mulher (DDM) no ano de 2013, bem como de seus agressores e mapeá-las por área de abrangência das Unidades de Saúde da Família. Metodologia: a análise dos dados será obtida por meio dos Boletins de Ocorrência realizados na Delegacia de Defesa da Mulher no ano de 2013. a amostra será composta por mulheres que realizaram boletim de ocorrência como vítimas de violência praticada pelo parceiro íntimo no período de janeiro a dezembro de 2013. em média são realizados 30 boletins de ocorrência por mês, totalizando, em média, 360 no ano. Trata-se de recorte de uma pesquisa de pós-doutorado que constará de duas etapas, na primeira será realizada a caracterização do perfil das mulheres e agressores, na segunda serão investigadas as mulheres que relataram sofrer violência há mais de cinco anos, sendo realizada entrevista individual gravada. Além disso, será realizado o mapeamento dos serviços de saúde buscando por estas mulheres visando identificar quais foram os encaminhamentos e intervenções realizados pelos profissionais. Resultados: 0 levantamento do perfil social e demográfico das mulheres e agressores possibilitará aos serviços de saúde a reorganização de suas práticas e a construção de estratégias de detecção e acompanhamento das mulheres, bem como articular com a rede de serviços e politicas municipais a elaboração de protocolos, fluxos e procedimentos. Consideramos a importância dos dados subsidiarem futuros trabalhos científicos e ações práticas de intervenção com as referidas mulheres. Conclusão: o reconhecer dos perfis possibilita ampla visão do processo saúde doença de mulheres vítimas de violência.

Pierine, Andrea Silveira Machado; Machado, Dinair Ferreira; Conti, Elaine Teixeira da Costa; Almeida, Margareth Ap. Santini de; Castanheira, Elen Rose Lodeiro. Conhecer para Humanizar: Caracterização do Perfil de Mulheres que Denunciaram a Violência em um Município do Interior Paulista.. In: Anais do Congresso Internacional de Humanidades \& Humanização em Saúde [= Blucher Medical Proceedings, num.2, vol.1]. São Paulo: Editora Blucher, 2014. ISSN 2357-7282

DOI 10.5151/medpro-cihhs-10393 